\title{
MEDIA PEMBELAJARAN BAHASA ARAB BERBASIS ANDROID DENGAN MENGGUNAKAN APLIKASI ARRUZ UNTUK PENGUASAAN NAHWU DI JURUSAN SASTRA ARAB UIN SUNAN KALIJAGA YOGYAKARTA
}

\author{
Abrar Sulhadi \\ Universitas Islam Negeri Sunan Kalijaga Yogyakarta \\ sulhadiabror@gmail.com
}

\begin{abstract}
This research is a development research (research and development). The purpose of this research is the development of Arabic learning media for android-based mastery of nahwu, knowing the appropriateness of the media and knowing the increase in nahwu understanding of Arabic Language and Literature Department students of UIN Sunan Kalijaga Yogyakarta by using android application media. To find out the extent of the feasibility of using the media, the writer uses a richter scale with the categories of SB (Very Good), B (Good), C (Fair), KB (Not Good), TB (Not Good). The assessment was carried out by IT experts (deplovers) and material experts and 30 students as respondents. Meanwhile, to find out the increased use of this application media the authors use the $t$ test by doing pretest and posttest to 30 respondents. The results of the study based on the pretest and posttest that have been done 1) the use of android-based media applications can improve students' understanding in nahwu lessons 2 ) the results of different test mean analysis shows that the posttest score is greater than the pretest namely 84.00 and 60.33 with a difference of 23.67. 3) Paired t-test results show a 2-tailed value of 0,000 '0.005 which means that Android-based Arabic learning media can improve the understanding of students of Arabic Language and Literature Department at UIN Sunan Kalijaga Yogyakarta.
\end{abstract}

Keywords: media, nahwu learning, android, application

Abstrak: Penelitian ini merupakan penelitian pengembangan (research and devlopment). Tujuan dari penelitian ini adalah pengembangan media pembelajaran Bahasa Arab untuk penguasaan nahwu berbasis android, mengetahui kelayakan media tersebut serta mengetahui peningkatan pemahaman nahwu mahasiswa Jurusan Bahasa dan Sastra Arab UIN Sunan Kalijaga Yogyakarta dengan menggunakan media aplikasi android. Untuk mengetahui sejauh mana kelayakan penggunaan media tersebut, penulis menggunakan skala rikter dengan katagori nilai SB (Sangat Baik), B (Baik), C (Cukup), KB (Kurang Baik), TB (Tidak Baik). Penilaian dilakukan oleh ahli IT (deplover) dan ahli materi dan 30 mahasiswa sebagai responden. Sedangkan untuk mengetahui peningkatan penggunaan media aplikasi ini penulis menggunakan uji $t$ dengan melakukan pretest dan posttest kepada 
30 responden. Hasil penelitian berdasarkan pretest dan posttest yang telah dilakukan 1) penggunaan aplikasi media berbasis android dapat meningkatkan pemahaman mahasiswa dalam pelajaran nahwu 2) hasil analisi uji beda Mean menunjukan bahwa nilai posttest lebih besar dari pretest yaitu 84.00 dan 60.33 dengan selisih 23.67. 3) hasil uji Paired t-test menunjukan nilai 2-tailed sebesar $0.000<0.005$ yang berarti media pembelajaran Bahasa Arab berbasis android dapat meningkatkan pemahamn nahwu mahasiswa Jurusan Bahasa dan Sastra Arab UIN Sunan Kalijaga Yogyakarta.

Kata kunci: media, pemebelajaran nahwu, android, aplikasi

\section{A. Pendahuluan}

Ungkapan bijak mengatakan "gambar bernilai seribu kata", dengan memperlihakan gambar. Penjelasasn guru secara verbal yang bersifat abstrak dapat mudah dipahami oleh murid dan murid akan memperkaya pengetahuannya dengan kehadiran media tersebut. ${ }^{1}$

Bahasa merupakan usaha yang tidaklah mudah untuk digeluti terkadang sangat membosankan untuk menghafal beberapa qoidah dalam bahasa itu sendiri, bahkan kadangkala membuat orang frustasi karena membtuhkan waktu bertahun-tahun. Hal ini disebapkan karena belajar bahasa merupakan upaya untuk membangun konsep baru dalam diri seseorang. Konsep baru itu kadang berbeda sama sekali dengan konsep bahasa ibu, baik dari segi fonologi, morfologi, semantic dan sintaksisnya bisa jadi memeilik kemiripan dengan bahasa ibunya ${ }^{2}$

Perkembangan Teknologi Informasi dan Komunikasi (TIK) yang sangat pesat telah mempengaruhi berbagai bidang kehidupan bahkan merupakan suatu hal yang tidak asing lagi bagi kalangan masyarakat. ${ }^{3}$ pada masa sekarang ini Teknologi Informasi dan Komunikasi (TIK) memegang peranan penting, baik dalam bidang Pendidikan, ekonomi, sosial, budaya, geografi, agama, dan juga berbagai bidang lainnya.

Dalam bidang pendidikan, perkembangan Teknologi Informasi dan Komunikasi telah mengubah cara belajar murid, memperoleh berbagai informasi serta dalam menafsirkan informasi. Kecanggihan teknologi dalam pendidikan memberikan tantangan besar bagi pendidik untuk terus memainkan peran penting dalam mencerdaskan anak bangsa di era globalisasi.

Perkembangan system oprasi android mulai dari gadget, tablet PC, smartphone dan aplikasi lain yang memiliki system oprasi android lainnya. Tentunya dapat mendukungpeserta didikmemilikidanmenggunakanandroiddalamkehidupansehari-

1 Abdul Wahab Rosyid, Media Pembelajaran Bahasa Arab, UIN Malang press 2009, h (kata pengantar)

2 Ibid. 118

3 Purwo Wilayadi PLS UM, pemanfaatan perkembangan teknologi informasi dan Komunikasi untuk kemajuan pendidikan di Indonesia.jurnal ilmiah 
hari. Penggunaan smartphone sendiri telah populer di dunia dan tidak ketinggalan dengan Indonesia. Dengan adanya smartphone dapat memberikan dampak yang sangat besar bagi kehidupan manusia dan banyak memberikan kemudahan dalam penggunaannya. Namun, belakangan ini smartphone hanya digunakan untuk sosial media saja dan hanya sebagian kecil yang memanfaatkan untuk keperluan belajar. ${ }^{4}$

Pengguna handphone saat ini pada kalangan pelajar sudah sangat berkembang pesat, hampir semua pelajar telah menggunakan handphone. Seperti survey yang dilakukan oleh Ahmad Fauzi, dari 56 responden hanya 1 responden yang menyatakan tidak memiliki smartphone atau tablet. Dan dari ke 55 tersebut, 45 murid menggunakan handphone yang berbasis Android.5 Fenomena ini juga terjadi pada mahasiswa jurusan Sastra $\mathrm{Arab}^{5}$, kebanyakan para murid menggunkan handphone genggamnya nya untuk membuka aplikasi Facebook, Instagram, Twitter dan Game Online.

Arruz adalah media yang akan penulis ciptakan dan kembangkan digunkan untuk menegmbangkan pembelajaran Bahasa Arab, Arruz itu sendiri berasal dari bahasa Arab "ruzzun" yang berarti nasi, maksudnya adalah jika orang mengkonsumsi nasi tentu akan menimbulkan efek kenyang, begitupun dengan penggunaan aplikasi Arruz. Orang akan merasa memiliki banyak tambahan ilmu pengetahuan di bidang pelajaran Bahasa Arab khususnya ilmu nahwu.

Arruz ini merupakan sebuah softwere yang akan digunakan dalam pembelejaran Bahasa Arab yang memiliki bebreapa fitur-fitur yaitu berupa permainan dengan mengandalkan bank soal dari tingkat pemula sampai dengan expert, fitur lainnya adalah dilengkapi dengan kamus nahwu dan sharafyang bertujuanuntuk memudahkan mahasiswa mencari kosakata sulit dari penegrtian istilah-istilah kaidah, itu semua disajikan dalam satu aplikasi yang bernama Arruz.

\section{B. Landasan Teori}

\section{Urgensi Media Pembelajaran Berbasis Android}

Kata media berasal dari bahasa Latin medius, jika diterjemahkan secara harfiah memiliki makna tengah "perantara" atau pengantar. ${ }^{6}$ Dalam pembelajaran bahasa, salah satu media yang bisa digunakan adalah media android yang diaplikasikan ke dalam sebuah smartphone yang berbentuk aplikasi. Nana Suhjana dan Ahamad Rivai (2007) dalam bukunya mengatakan bahwa pemanfaatan media audio dalam pengajaran terutama digunakan dalam: pertama, pengajaran musik literary (pembacaan sajak), dan kegiatan dokumentasi. Kedua, pengajaran bahasa asing, baik secara audio maupun audio visual. Ketiga, pengajaran melalui radio. Keempat, paket-

4 Musyaroh, Mega. "pengembangan media pembelajaran berbasis android dengan menggunakan aplikasi android aplikasi adobe flash cs 6 pada mata pelajaran biologi”. Vol 6, Nomor 2 Desember 2017.

5 http://lembing.com/data-pengguna-smartphone-dan-social-media-2015/ diakses pada 1 Desember 2018

6 Azhar Arsyad, Media Pembelajaran, (Jakarta: RajaGrafindo Persada, 2011), hlm. 3 
paket belajar untuk berbagai jenis materi, yang memungkinkan murid dapat melatih daya penafsirannya dalam suatu bidang studi.?

Dengan mengguanakan pembelajaran berbasis android yang diterapkan kedalam sebuah aplikasi pengalaman belajar yang diperoleh murid akan semakin bertambah. Murid tidak hanya mendapatkan keterangan berupa kata-kata tapi mendapatkan pengalaman nyata dari visual yang ditampilakan. Amir Hamzah Sulaiman menyebutkan. Bahwa, alat-alat visual tidak saja menghasilkan cara belajar yang efektif dalam waktu singkat, tetapi apa yang ditrima melalui kata-kata lebih lama dan lebih baik ditingal dalam ingatan. ${ }^{8}$

\section{a. Pengertian Android}

Android merupakan sebuah sistem oprasi berbasis Linux yang di disain khusus untuk prangkat bergerak seperti smartphone atau tablet. Sistem oprasi android bersifat open scoure. ${ }^{9}$ Android menyediakan platfom terbuka bagi para pengembang untuk menciptakan aplikasi mereka sendiri untuk digunakan oleh bermacam pranti perangkat.

Awal perkembangan android mulai naik tajam pada tahun 2007 dimana Google mulai mendaftarkan paten android di bidang telepon seluler. Langkah Google ini ternyata mengundang banyak perhatian. Bagaimana tidak, sebuah "Mesin Pencari Raksasa" mulai merambah ke dunia ponsel dengan sistem operasi yang baru. Akhirnya berbagai perusahaan ponsel semakin banyak yang menggunakan android dalam sistem operasi ponselnya. ${ }^{10}$

Antarmuka pengguna android didasarkan pada manipulasi langsung, menggunakan masukan sentuh yang serupa dengan tindakan di dunia nyata, seperti menggesek, mengetuk, mencubit, dan membalikkan cubitan untuk memanipulasi obyek layar. android adalah sistem operasidengan sumber terbuka (Open Source), dan Google merilis kodenya di bawah Lisensi Apache. ${ }^{11}$

\section{b. Android Dalam Dunia Pendidikan}

Android tidak hanya digunakan untuk keperluan hiburan dan pekerjaan. Namun dengan sifatnya yang memiliki basis devloper yang besar untuk mengembangkan aplikasi, membuat fungsi android menjadi lebih luas dan beragam. Android plus pendidikan memungkinkan kita membuat sebuah collaborative learning. Yaitu sebuah lingkungan belajar dimana banyak orang yang bergabung mengerjakan suatu pekerjaan bersama-sama, saling memberi feedback sehingga menghasilkan sesuatu

7 Sudjana dan Rivai, Media Pengajaran, (Bandung: Sinar Baru Algensindo, cet 7, 2007) hlm 129

8 Amri Sulaiman, Media Audio Visual, (Jakarta: PT Gramedia), hlm 18

9 Arif Akbarul Huda, live Coding! 9 Aplikasi Android Buatan Sendiri, CV Andi Offset (penerbit Andi), Yogyakarta, 2013, hlm. 3

10 Ciu Bung Seng, Android: Dasar Pengoperasian, Optimasi sampai Modifikasi, (Jakarta: Jasakom, 2011), hlm. 2

11 Ciu Bung Seng, Android ..., hlm. 3 
yang sempurna, di Eropa dan Amerika seudah terbiasa mengerjakan project (riset). Setelah mendapatkan materi dari guru, guru memberi tugas riset yang berhubungan dengan materi tersebut secara kelompok. Karena tiap orang memiliki pandangan yang berbeda, itulah yang akan membaut suatu pembelajaran lebih cepat dimengerti dan meghasilkan suatu yang luar biasa.

\section{Aplikasi Arruz}

Aplikasi Arruz merupakan sebuah softwere yang terdapat di android yang dirancang untuk media pembelajaran agar dapat memudahkan murid(user)dalam memahmi pelajaran Bahasa Arab. Arruz adalah nama yang penulis pilih untuk sebuah softwere yang akan digunakan oleh peneliti sebagai bahan uji coba dalam peningkatan mutu pembelajaran Bahasa Arab khususnya pada mata pelajaran ilmu nahwu, aplikasi ini dibuat dan dikembangkan sendiri oleh penulis sebagai bahan tambahan media pembelajaran di dalam dunia pendidikan.

Bermula aplikasi ini muncul di benak penulis karena melihat permasalahanpermasalahan pada murid yang kesulitan dalam belajar nahwu dan memakan waktu lama, bahkan sampai bertahun-tahun, juga murid sangat kesulitan dalam belajar secara otodidak tanpa didampingi oleh pemandu. Maka dari itu, kehadiran aplikasi ini untuk menjawab probelem yang ada sekaligus sebagai pemandu murid dalam mengulang pelajaran lebih khususnya dalam bidang nahwu

Arruz asal katanya diambil dari bahasa Arab ruzzun yang berarti 'nasi”. Mengapa diberi nama demikian. Karena penulis berangapan bahwa, nasi merupakan kebutuhan pokok dalam rantai makanan dan merupakan makanan dasar. Nasi akan terasa sangat enak bila dicampur dengan lauk pauk begitu pula terhadap pembelajarn Bahasa Arab terutama dibidang nahwu. Ilmu nahwu merupakan pokok dari bahasa Arab, bagaimana mungkin orang akan paham dengan bahasa Arab apabila nahwu dasar tidak dikuasai, dan nahwuakan menajdi indah bila ditambah dengan saraf, balagah, arud, tasrif, dan komponen pendukung di dalam bahasa Arab. Itu semu merupakan lauk pauk dari ilmu nahwu.

Aplikasi ini berfungsi untuk mempermudah murid dalam mempelajari kaidahkaidah bahasa, karena didalam aplikasi ini terdapat bank kamus kaidah nahwu dan saraf yang merupakan ilmu vital dalam Bahasa Arab serta bermuatn khusus mempelajari bahasa Arab dalam bentuk digital. Sehingga murid akan tertarik dalam belajar sambil bermain.

Aplikasi Arruz menyediakan kamus nahwu dan saraf, yaitu berisi tentang kaidah-kaidah yang terdapat pada nahwu dan sharaf beserta penjelasannya dan juga contoh-contoh kongkrit yang terdapat dalam kaidah yang dicari, contoh-contoh yang penulis pakai diambil dari syair para penyair, Alquran dan juga ungkapan-ungkapan masyhur.

Didalam banyak kitab, memang sangat banyak kita temukan kaidah-kaidah nahwu dan saraf. Namun, apa yang membedaknnya dengan aplikasi yang digunakan. 
Didalam pembahsan ilmu nahwu kaidah-kaidah yang digunakan dalam menerangkan kadang terlihat random (acak) dan sukar untuk dimengerti. Maka dari itu aplikasi ini menawarkan efesiensi waktu dalam memahami dan mencari kata yang sukar dipahami maknanya.

\section{Metode Penelitian}

\section{Pendekatan dan Jenis Penelitian}

Pendekatan ini menggunakan pendekatan kualitatif dan kuantitatif sedangkan Jenis penelitian yang digunakan dalam penyusunan aplikasi ini merupakan jenis penelitian Research and Development. ${ }^{12}$ Model penelitian ini bersifat deskriptif, menggariskan tahap-tahap yang harus diikuti untuk menghasilkan produk berupa aplikasi pembelajaran Pendidikan bahasa Arab.

Secara umum, proses Research and Development adalah sebagai berikut: ${ }^{26}$

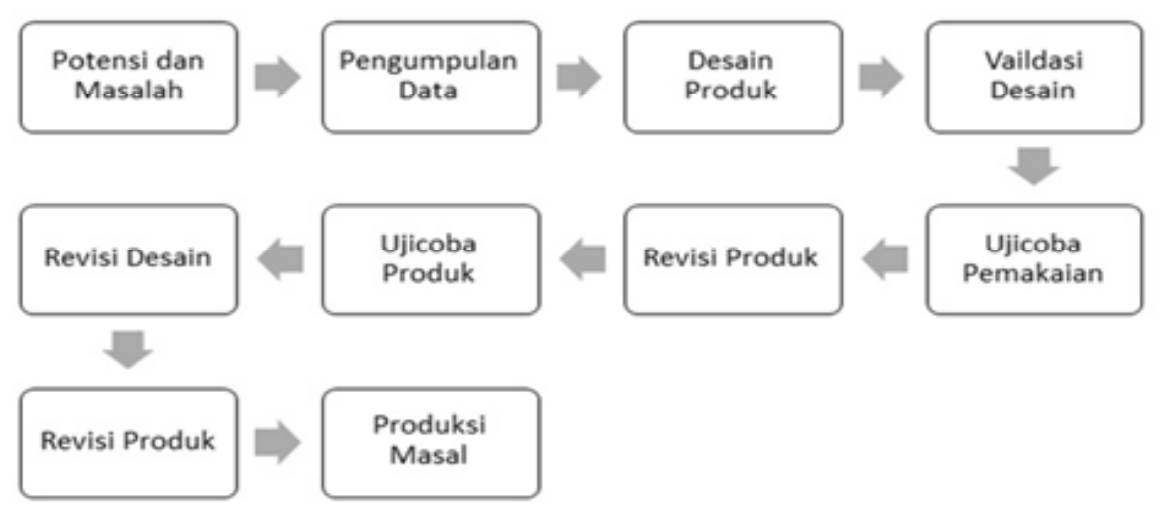

\section{Langkah-langkah Penelitian}

\section{a. Subjek Penelitian}

Subjek penelitian yang dipilih adalah tim ahli yang memahami dunia pendidikan dan dunia komputer agar mendapatkan penilaian dan masukan yang sesuai sebelum diterapkan di dunia pendidikan. Tim ahli tersebut adalah:

1. Peninjau adalah Dosen Media Pembelajaran.

2. Penilai kualitas adalah Dosen Media Pembelajaran, 1 guru Bahasa Arab dan 1 ahli devloper.

3. Penilai Tampilan untuk Pengguna Akhir (End User) adalah 5 murid

\section{b. Jenis Data}

Data dalam penelitian ini dapat diklarifikasikan menjadi dua data. Pertama, data kuantitatif yang berupa kritik dan saran dari para ahli, guru dan santri. Kedua,

12 Direktorat Tenaga Kependidikan, Direktorat Jenderal Peningkatan Mutu Pendidik dan Tenaga Kependidikan, Pendekatan, Jenis, dan Metode Penelitian Pendidikan, (Departemen Pendidikan Nasional, 2008), hlm. 47 
data kuantitatif melalui hasil analisis validasi para ahli, respon dan hasil pretest dan posttest.

Data kunatitatif lalu dikonversikan menjadi data kuantitatif, setelah itu data analisis dengan menggunakan analisis deskriftif, dalam hal ini untuk mendeskripsikan hasil dari validasi, respon siswa dan kesimpulan dari dampak penggunaan media apliksi android untuk pembelajran materi nahwu melalui hasil analisis dari uji hipotesis.

\section{c. Teknik Pengumpulan Data}

Untuk mendapatkan data-data yang relevan dengan tujuan penelitian, maka digunakan tehnik-tehnik pengumpulan data sebagai berikut:

1. Observasi

2. Wawancara

3. Dokumentasi

4. Angket

5. Tes

\section{d. Analisis Data}

Teknik yang digunakan daam penelitian ini ada 2 bagian, yaitu tehnik analisis isi dan tehnik analysis deskriftif persentase. Tehnik analisis isi peneliti gunakan untuk menganalisis data yang diproleh dari para ahli berupa saran dan masukan, sedangkan tehnik analisis deskriftif persentase digunakan untuk mengolah data yang dapat dari hasil uji coba kelompok kecil dan uji coba lapangan. Hasil analisis data menjadi dasar dalam penyempurnaan penelitian pengembangan ini. Setelah data terkumpul, maka selanjutnya dilakukan proses analisis data (pengolahan data). Berikut proses analisis data tersebut:

\section{Analisis deskriftif}

Analisi data deskriftif ini digunakan untuk mendeskripsikan hasil validasi produk yang telah dinilai oleh ahli media dan ahli materi serta respon mahasiswa. Analisis deskriftif dilakukan dengan menggunakan statistic deskriptif

2. Analisis dan Eksperimen

Bila data berdistribusa normal, untuk menganalisis data yang diperoleh dari lapangan, peneliti menggunakan analisis kuantitatif, yaitu analisis yang mengguanakan analisis yang bersifat kuantitatif, berupa alat analisis yang menggunakan model-model seperti matematika, statistic dan ekonometri. ${ }^{13}$ Dalam analisis kuantitatif ini peneliti menggunakan model 
statisitik. Untuk mengetahui apakah pretest dan posttest yang sedang diperbandingkan secara signifikan memang berbeda disebapkan oleh perlakuan dalam penelitian tersebut atau sekedar kebetulan belaka, dalam penelitian menggunakan test " $\mathfrak{t}$ " sebagai teknik analisisnya. ${ }^{14}$

\section{Hasil dan Pembahasan \\ 1. Penyajian data dan analisis}

Evaluasi digunakan untuk memperoleh data yang akan digunakan untuk merevisi produk yang dikembangkan yaitu media pembelajaran bahasa Arab nahwu berbasis android. Evaluasi yang dilakukan ini adalah proses menyediakan dan informasi untuk dijadikan dasar pengambilan keputusan untuk meningkatkan kualitas media yang dikembangkan dilihat dari aspek IT dan aspek maeri.

Data yang diperoleh dari kedua validasi ahli dan juga data hasil angket mahasiswa disajikan dan dianalisis lebih lanjut dari pembahasan berikut:

\section{Respon Mahasiswa Jurusan Bahasa dan Sastra Arab Fakultas Adab dan Ilmu Budaya UIN Sunan Kalijaga Yogyakarta}

Setelah media direvisi berdasarkan masukan penilaian dari validator maka selanjutnya dilakukan uji lapangan. Mahasiswa Jurusan Bahasa dan Sastra Arab UIN Sunan Kalijaga diminta untuk mengisi kuisioner yang telah peneliti siapkan untuk memberi tanggapan terhadap media aplikasi, para mahasiswa memberi skor pada aspek desain dan materi dalam aplikasi. Penilaian mahasiswa pada aspek ini diberikan rentang skor skala lima, untuk setiap indikator dengan keternagan sebagai berikut: 1) tidak baik, 2) kurang, 3) cukup, 4) baik, 5) sangat baik.

Uji coba lapangan dilakukan oleh 30 mahasiswa yang merupakan mahasiswa jurusan bahasa dan sastra arab semester 3 dan 1 . Adapun nama mahasiswa tersebut penulis jelaskan dalam lampiran.

a. Penilaian aspek desain mahasiswa Jurusaan Bahasa dan Sastra Arab Universitas Islam Negeri Sunan Kalijga

Item penilaian aspek desain meliputi: 1) tampilan aplikasi menarik, 2) tampilan materi aplikasi sesuai, 3) pengguanaan aplikasi mudah dimengeri, 4) ukuran font dan gambar aplikasi mudah dibaca, 5) warna pada aplikasi sesuai, 6) penempatan deskripsi materi membingungkan, 7) aplikasi membantu pembelajaran bahasa Arab

Dari indikator yang telah penulis paparkan, maka hasil pengisian angket oleh responden penulis jelaskan dalam lampiran. Dari data tersebut kemudian dianalisis dengan menghitung rata-rata nilai jawaban berdasarkan skoring setiap jawaban responden. Analisis tersebut menggunakan tehnik penetapan keriterium skala lima berdasarkan gambar kontinum yang menunjukan letak rata-rata nilai jawaban 
tersebut. Letak itulah yang dijadikan keriteria kualitasnya. Analisi tersebut dipaparkan sebagai berikut:

1. Secara kontinum hasil rerata skor item 1 dari 30 responden dalam penilaian aspek desain dapat digambarkan sebagai berikut:

\begin{tabular}{l|l|l|l|l}
\hline SB & B & C & KB & TB \\
5 & & & & \\
\hline 4,5 & 4 & 3 & 2 & 1 \\
\hline
\end{tabular}

Dengan ketentuan SB = Sangat Baik B = Baik C = Cukup KB = Kurang Baik $\mathrm{TB}=$ Tidak baik. Jadi berdasarkan data yang diperoleh dari item 1 maka rata-rata 4,5 terletak pada daerah baik

2. Secara kontinum hasil rerata skor item 2 dari 30 responden dalam penilaian aspek desain dapat digambarkan sebagai berikut:

\begin{tabular}{l|l|l|l|l}
\hline SB & B & C & KB & TB \\
5 & & & & \\
\hline $\mathbf{4 , 2}$ & 4 & 3 & 2 & 1 \\
\hline
\end{tabular}

Dengan ketentuan SB = Sangat Baik B = Baik C = Cukup KB = Kurang Baik $\mathrm{TB}=$ Tidak baik. Jadi berdasarkan data yang diperoleh dari item 2 maka rata-rata 4,2 terletak pada daerah baik

3. Secara kontinum hasil rerata skor item 3 dari 30 responden dalam penilaian aspek desain dapat digambarkan sebagai berikut:

\begin{tabular}{l|l|l|l|l}
\hline SB & B & C & KB & TB \\
5 & & & & \\
\hline 4,5 & 4 & 3 & 2 & 1 \\
\hline
\end{tabular}

Dengan ketentuan SB = Sangat Baik B = Baik C = Cukup KB = Kurang Baik $\mathrm{TB}=$ Tidak baik. Jadi berdasarkan data yang diperoleh dari item 3 maka rata-rata 4,5 terletak pada daerah baik

4. Secara kontinum hasil rerata skor item 4 dari 30 responden dalam penilaian aspek desain dapat digambarkan sebagai berikut:

\begin{tabular}{l|l|l|l|l}
\hline SB & B & C & KB & TB \\
\hline 5 & & & & \\
\hline $\mathbf{4 , 1}$ & 4 & 3 & 2 & 1 \\
\hline
\end{tabular}

Dengan ketentuan SB = Sangat Baik B = Baik C = Cukup KB = Kurang Baik $\mathrm{TB}=$ Tidak baik. Jadi berdasarkan data yang diperoleh dari item 4 maka rata-rata 4,1 terletak pada daerah baik

5 Secara kontinum hasil rerata skor item 5 dari 30 responden dalam penilaian aspek desain dapat digambarkan sebagai berikut: 


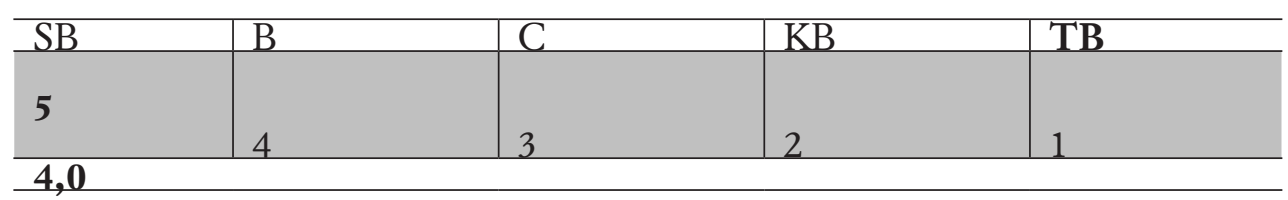

Dengan ketentuan SB = Sangat Baik B = Baik C = Cukup KB = Kurang Baik $\mathrm{TB}=$ Tidak baik. Jadi berdasarkan data yang diperoleh dari item 5 maka rata-rata 4,0 terletak pada daerah baik

6. Secara kontinum hasil rerata skor item 6 dari 30 responden dalam penilaian aspek desain dapat digambarkan sebagai berikut:

\begin{tabular}{l|l|l|l|l}
\hline SB & B & C & KB & TB \\
$\mathbf{5}$ & & & & \\
\hline $\mathbf{4 , 6}$ & 4 & 3 & 2 & 1 \\
\hline
\end{tabular}

Dengan ketentuan SB = Sangat Baik B = Baik C = Cukup KB = Kurang Baik $\mathrm{TB}=$ Tidak baik. Jadi berdasarkan data yang diperoleh dari item 6 maka rata-rata 4,6 terletak pada daerah baik

7. Secara kontinum hasil rerata skor item 7 dari 30 responden dalam penilaian aspek desain dapat digambarkan sebagai berikut:

\begin{tabular}{l|l|l|l|l}
\hline SB & B & C & KB & TB \\
\hline $\mathbf{5}$ & & & & \\
& 4 & 3 & 2 & 1 \\
\hline $\mathbf{4 , 0}$ & & & \\
\hline
\end{tabular}

Dengan ketentuan SB = Sangat Baik B = Baik C = Cukup KB = Kurang Baik $\mathrm{TB}=$ Tidak baik. Jadi berdasarkan data yang diperoleh dari item 7 maka rata-rata 4,0 terletak pada daerah baik.

8. Secara kontinum hasil rerata skor item 8 dari 30 responden dalam penilaian aspek desain dapat digambarkan sebagai berikut:

\begin{tabular}{l|l|l|l|l}
\hline SB & B & C & KB & TB \\
\hline $\mathbf{5}$ & & & & \\
& 4 & 3 & 2 & 1 \\
\hline
\end{tabular}

Dengan ketentuan $\mathrm{SB}=$ Sangat Baik $\mathrm{B}=$ Baik $\mathrm{C}=$ Cukup KB $=$ Kurang Baik $\mathrm{TB}=$ Tidak baik. Jadi berdasarkan data yang diperoleh dari item 8 maka rata-rata 4,7 terletak pada daerah baik.

Secara kontinum hasil rerata total skor pada 8 item dari 30 responden dalam penelitian aspek desain dapat digambarkan sebagai berikut:

\begin{tabular}{l|l|l|l|l}
\hline SB & B & C & KB & TB \\
\hline $\mathbf{5}$ & & & & \\
& 4 & 3 & 2 & 1 \\
\hline $\mathbf{4 , 3}$
\end{tabular}


Dengan ketentuan SB = Sangat Baik B = Baik C = Cukup KB $=$ Kurang Baik $\mathrm{TB}=$ Tidak baik. Jadi berdasarkan data yang diperoleh dari item 6 maka rata-rata 4,3 terletak pada daerah baik. Hal ini menunjukan respon mahasiswa terhadap desain media pembelajaran bahasa Arab nahwu berbasis android mempunyai skor kriterium baik.

b. Penilaian Aspek Materi Mahasiswa Jurusan Bahasa dan Sastra Arab Universitas Islam Negeri Sunan Kalijga

Adapun item penilaina dari aspek materi meliputi: 1) kejelasan deskripsi pada setiap kata, 2) penjelasan kaidah mudah dipahami, 3) contoh yang diberikan membantu memahami materi, 4) kaidah yang dijelaskan sesuai dengan contoah, 5) kejelasan deskripsi kaidah, 6) kelengkapan kaidah yang disajikan, 7) aplikasi yang digunakan dapat memudahkan pelajaran bahas arab, 8) pembelajaran nahwu menynangkan dengan aplikasi ini.

Dari data tersebut kemudian dianalisis dengan menghitung rata-rata jawaban berdasarkan skoring setiap jawaban dari responden. Analisis tersebut menggunakan tehnik penetapan kriterium skala lima berdasarkan gambar kontinum yang menunjukan letak rata-rata nilai jawaban tersesbut. Letak itulahdijadikan keriteria kualitatifnya. Analisa tersebut dipaprkan berikut ini:

1. Secara kontinum hasil rerata skor item 1 dari 30 responden dalam penilaian aspek materi dapat digambarkan sebagai berikut:

\begin{tabular}{l|l|l|l|l}
\hline SB & B & C & KB & TB \\
\hline $\mathbf{5}$ & & & & \\
\hline $\mathbf{4 , 3}$ & 4 & 3 & 2 & 1 \\
\hline
\end{tabular}

Dengan ketentuan SB = Sangat Baik B = Baik C = Cukup KB = Kurang Baik $\mathrm{TB}=$ Tidak baik. Jadi berdasarkan data yang diperoleh dari item 6 maka rata-rata 4,3 terletak pada daerah baik

2. Secara kontinum hasil rerata skor item 2 dari 30 responden dalam penilaian aspek materi dapat digambarkan sebagai berikut:

\begin{tabular}{l|l|l|l|l}
\hline SB & B & C & KB & TB \\
$\mathbf{5}$ & & & & \\
\hline $\mathbf{4 , 4}$ & 4 & 3 & 2 & 1 \\
\hline
\end{tabular}

Dengan ketentuan SB = Sangat Baik B = Baik C = Cukup KB = Kurang Baik $\mathrm{TB}=$ Tidak baik. Jadi berdasarkan data yang diperoleh dari item 6 maka rata-rata 4,4 terletak pada daerah baik

3. Secara kontinum hasil rerata skor item 3 dari 30 responden dalam penilaian aspek materi dapat digambarkan sebagai berikut: 


\begin{tabular}{l|l|l|l|l}
\hline SB & B & C & KB & TB \\
$\mathbf{5}$ & & & & \\
\hline $\mathbf{4 , 2}$ & 4 & 3 & 2 & 1 \\
\hline
\end{tabular}

Dengan ketentuan SB = Sangat Baik B = Baik C = Cukup KB = Kurang Baik $\mathrm{TB}=$ Tidak baik. Jadi berdasarkan data yang diperoleh dari item 6 maka rata-rata 4,2 terletak pada daerah baik

4. Secara kontinum hasil rerata skor item 4 dari 30 responden dalam penilaian aspek materi dapat digambarkan sebagai berikut:

\begin{tabular}{l|l|l|l|l}
\hline SB & B & C & KB & TB \\
$\mathbf{5}$ & & & & \\
\hline $\mathbf{4 , 2}$ & 4 & 3 & 2 & 1 \\
\hline
\end{tabular}

Dengan ketentuan SB = Sangat Baik B = Baik C = Cukup KB = Kurang Baik $\mathrm{TB}=$ Tidak baik. Jadi berdasarkan data yang diperoleh dari item 6 maka rata-rata 4,2 terletak pada daerah baik

5. Secara kontinum hasil rerata skor item 5 dari 30 responden dalam penilaian aspek materi dapat digambarkan sebagai berikut:

\begin{tabular}{l|l|l|l|l}
\hline SB & B & C & KB & TB \\
\hline $\mathbf{5}$ & & & & \\
\hline $\mathbf{3 , 8}$ & 4 & 3 & 2 & 1 \\
\hline
\end{tabular}

Dengan ketentuan $\mathrm{SB}=$ Sangat Baik B $=$ Baik $\mathrm{C}=$ Cukup KB $=$ Kurang Baik $\mathrm{TB}=$ Tidak baik. Jadi berdasarkan data yang diperoleh dari item 6 maka rata-rata 3,8 terletak pada daerah baik

6. Secara kontinum hasil rerata skor item 6 dari 30 responden dalam penilaian aspek materi dapat digambarkan sebagai berikut:

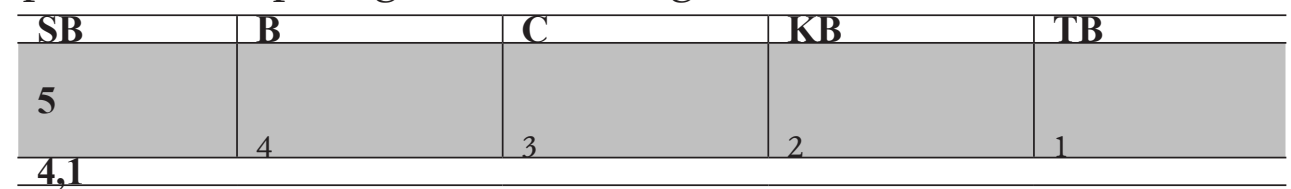

Dengan ketentuan SB = Sangat Baik B = Baik C = Cukup KB = Kurang Baik $\mathrm{TB}=$ Tidak baik. Jadi berdasarkan data yang diperoleh dari item 6 maka rata-rata 4,1 terletak pada daerah baik.

7. Secara kontinum hasil rerata skor item 7 dari 30 responden dalam penilaian aspek materi dapat digambarkan sebagai berikut:

\begin{tabular}{l|l|l|l|l}
\hline SB & B & C & KB & TB \\
5 & & & & \\
\hline $\mathbf{4 , 4}$ & 4 & 3 & 2 & 1 \\
\hline
\end{tabular}


Dengan ketentuan SB = Sangat Baik B = Baik C = Cukup KB $=$ Kurang Baik $\mathrm{TB}=$ Tidak baik. Jadi berdasarkan data yang diperoleh dari item 6 maka rata-rata 4,4 terletak pada daerah baik

8. Secara kontinum hasil rerata skor item 8 dari 30 responden dalam penilaian aspek materi dapat digambarkan sebagai berikut:

\begin{tabular}{l|l|l|l|l}
\hline SB & B & C & KB & TB \\
\hline 5 & & & & \\
\hline 4,4 & 4 & 3 & 2 & 1 \\
\hline
\end{tabular}

Dengan ketentuan SB = Sangat Baik B = Baik C = Cukup KB = Kurang Baik $\mathrm{TB}=$ Tidak baik. Jadi berdasarkan data yang diperoleh dari item 6 maka rata-rata 4,4 terletak pada daerah baik. Kesimpulan dari rerata skor yang diperoleh dari data hasil penilaian/tanggapan mahasiswa dari aspek materi adalah sebagai berikut:

Secara kontinum hasil rerata total skor pada 8 item dari 30 responden dalam penilaian aspek materi dapat digambarkan sebagai berikut:

\begin{tabular}{l|l|l|l|l}
\hline SB & B & C & KB & TB \\
5 & & & & \\
4,2 & 4 & 3 & 2 & 1 \\
\hline
\end{tabular}

Dengan ketentuan SB = Sangat Baik B = Baik C = Cukup KB = Kurang Baik $\mathrm{TB}=$ Tidak baik. Jadi berdasarkan data yang diperoleh dari item 6 maka rata-rata 4,2 terletak pada daerah baik. Hal ini menunjukan respon mahasiswa terhadap materi media pembelajaran nahwu bahasa Arab berbasis android mempunyai skor kriterium baik.

\section{Respon Mahasiswa Jurusan Bahasa dan Sastra Arab Universitas Islam Negeri Sunan Kalijga}

Respon mahasiswa terhadap media pembelajaran bahsa Arab nahwu berbasis android dapat disimpulkan sebagai berikut:

a. Terhadap aspek desain para mahasiswa memberikan skor rerata 4,3. Jadi berdasarkan data yang diperoleh dari rerata skor item pernyataan dari 30 responden maka rata-rata 4,3 terletak pada daerah baik. Hal ini menunjukan respon mahsiswa terhadap desain android mempunyai skor kriterium baik.

b. Terhadap aspek materi mahasiswa memberikan skor rerata 4,2. Jadi berdasarkan data yang diperoleh dari total rerata skor item pernyataan dari 30 responden rata-rata 4,2 terletak pada daerah baik. Hal ini menunjukan respon mahsiswa terhadap materi media pembelajaran nahwu bahasa Arab berbasis android mempunyai skor kriterium baik. 


\section{Dampak Penggunaan Media Aplikasi Android Untuk Penguasaan Nahwu}

Efektivitas penggunaan media aplikasi android dapat diketahui dengan diadakannya pretest dan posttest. Lalu membandingkan keduanya apakah ada perbedaan hasil selisih yang signifikan atau tidak antara sebelum dan sesudah menggunakan media tersebut dalam pembelajaran Bahasa Arab materi nahwu

Adapun prosedur dalam mengambil data tersebut adalah sebagai berikut:

1. Pengambilan data melalui pretest tujuannya untuk mengetahui kemampuan awal mahasiswa Jurusan Bahasa dan Sastra Arab.

2. Proses pembelajaran materi nahwu dengan menggunakan media android.

3. Pengambilan data melalui posttest tujuannya untuk mengetahui hasil belajar mahasiswa setelah diadakan pembelajaran materi nahwu dengan menggunakan media aplikasi android.

Kalkulasi nilai pretest dan posttest selama 2 kali perlakuan pembelajaran nahwu dengan menggunakan aplikasi android penulis uraikan sebagai berikut:

Langkah uji hipotesis dampak penggunaan media aplikasi android untuk pembelajaran maeri nahwu:

\section{a. Uji Prasyarat}

\section{Uji Normalitas}

Sebelum dilakukan analisis data maka dilakukan uji prasyarat terlebih dahulu yaitu uji normalitas dan uji homogenitas. Uji normalitas bertujuan untuk menguji normal tidaknya sebaran data dengan mengukur skor hasil prestasi belajar materi nahwu sebelum dan seudah menggunakan media aplikasi android. Sedangkan uji homogenitas digunakan untuk menguji apakah data pretest dan posttest berasal dari varian sejenisnya.

Melalui perhitungan dari SPSS menggunakan rumus Shapiro Wilk didapatkan nilainormalitas untuk data hasil tessesudah pembelajaran materinahwu menggunakan android (posttest) diperoleh taraf signifikan 0,09, sehingga dapat disimpulkan bahwa data untuk nilai posttest berdistribusi normal dan pretest dari perhitungan data 0,026, maka disimpulkan data nilai pretest berdistribusi normal sebagaimana yang ditampilkan dengan histogram daan grafik dibawah ini:

Table 4.8

Uji Normalitas

\begin{tabular}{c|c|c|c|c|c|c}
\hline \multirow{2}{*}{ Kelompok } & \multicolumn{3}{|c|}{ Kolmogroov-Smirnov } & \multicolumn{3}{c}{ Shapiro-Wilk } \\
\cline { 2 - 7 } & Statistic & Df & Sig & Statistic & Df & Sig \\
\hline Pretest & .187 & 30 & .009 & .919 & 30 & .026 \\
posttest & .197 & 30 & .004 & .901 & 30 & .009 \\
\hline
\end{tabular}


a. Lillefors Significane Correction

\section{Histogram For kelompok pretest}

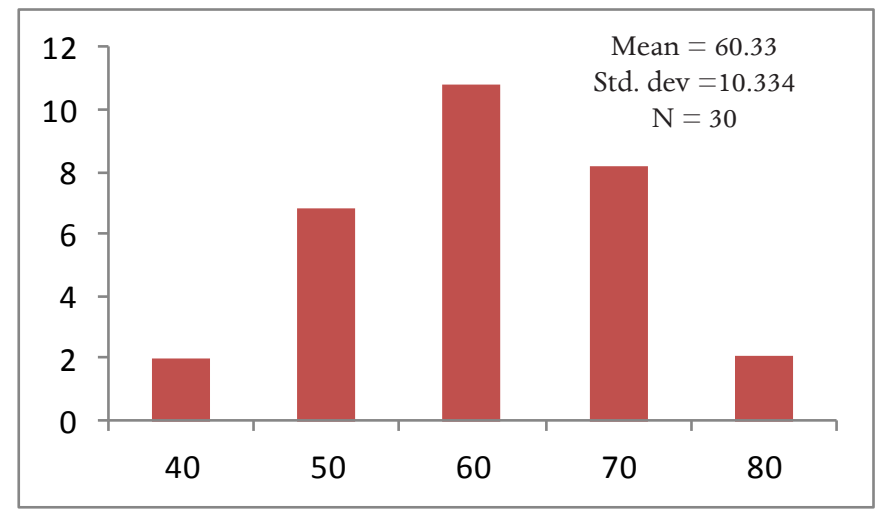

Diagram.4.5 Histogram Pretest

Histogram For kelompok $=$ posttest

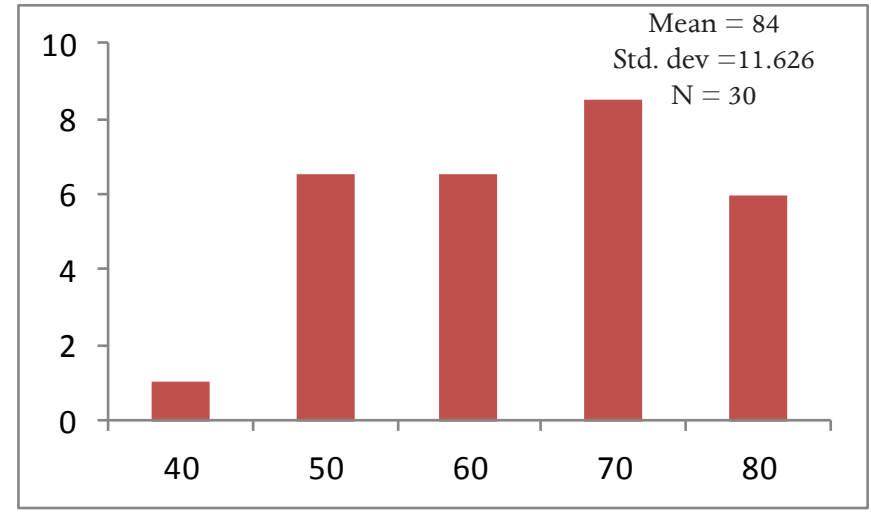

Diagram.4.7 Histogram Posttest

b. Uji Homogenitas

Melalui perhitungan statistik dengan bantuan SPSS menggunakan rumus one way anova didapatkan taraf signifikasi sebesar 0,168>0,05, maka dapat disimpulkan bahwa nilai posttest dan nilai pretest bersifat homogeny

Tabel.4.9

Homogenitas Pretest dan Postest

\begin{tabular}{c|c|c|c}
\hline Levene Statistik & Df1 & Df2 & Sig \\
\hline 1.951 & 1 & 58 & .168 \\
\hline
\end{tabular}

2. Uji Hipotesa

Berdasarkan hasil pretest dan postest selanjutnya dilakukan uji hipotesa yaitu untuk mengetahui dampak penggunaan media android untuk pembelajaran materi nahwu pada semester 1 dan 3 Jurusan Bahasa dan sastra Arab dengan cara membandingakn nilai pretest dan postest.

Pengujian tingkat efektivitas menggunakan rumus uji-t dengan SPSS. Hasil pengelolaan data menggunakan program SPSS ditampilkan tabel sebagai berikut: 
Tabel. 4. 10

Hasil Uji-t

\begin{tabular}{rcccc}
\hline & Mean & $\mathrm{N}$ & Sid Deviatin & $\begin{array}{c}\text { Sid. Eror } \\
\text { Mean }\end{array}$ \\
\hline pair 1 pretest & 60.33 & 30 & 10.334 & 1.887 \\
posttest & 84.00 & 30 & 11.626 & 2.123 \\
\hline
\end{tabular}

Tabel statistik deskriptif dari data di atas menunukan bahwa rata-rata nilai posttest sesudah menggunakan produk media aplikasi android 84.00 dengan standar deviasi 11.626. Nilai rata-rata sebelum menggunakan produkk media aplikasi android sebesar 60.33 dengan standar deviasi 10.334

Berdasarkan hasil perhitungan melalui SPSS. Menujukan terjadi peningkatan perstasi belajar mahasiswa setelah menggunakan produk media aplikasi android dibandingkan sebelum menggunakan produk media aplikasi yang mempunyai rata-rata sebesar 60.33 dan sesudah menggunakan media aplikasi android menjadi 84.00 selanjutnya angka kirelasi antara kedua variasi nilai sebelum dan sesudah menggunakan media apliksi android adalah ebagai berikut:

Tabel. 4. 11

Kolerasi Signifikasi Pretest Posttest

\begin{tabular}{l|c|c|c}
\hline & $\mathrm{N}$ & Corelation & Sig \\
\hline Pair 1 pretest prostest & 30 & .563 & .001 \\
\hline
\end{tabular}

Tabel korelasi menunjukan bahwa angka korelasi antara kedua variabel nilai sebelum dan sesudah menggunakan produk media aplikasi android adalah 0.563 yang berarti kedua variasi tersebut memiliki hubungan yang erat.

Selanjutnya untuk mengetahui tingakt signifikan penggunaan media aplikasi android berdasarkan hipotesa awal tesis ini dapat dilihat pada tabel berikut ini:

Tabel. 4. 12

Paired Samples Test

\begin{tabular}{|c|c|c|c|c|c|c|c|c|}
\hline & \multicolumn{5}{|c|}{ Paired Diffrensess } & \multirow{3}{*}{$\mathrm{T}$} & \multirow{3}{*}{ Df } & \multirow{3}{*}{ Sig.2tabel } \\
\hline & \multirow[t]{2}{*}{ mean } & \multirow[t]{2}{*}{$\begin{array}{l}\mathrm{S} \quad \mathrm{i} \quad \mathrm{d} \\
\text { Deviation }\end{array}$} & \multirow{2}{*}{$\begin{array}{l}\text { Sid } \\
\text { Eror } \\
\text { mean }\end{array}$} & \multicolumn{2}{|c|}{$\begin{array}{l}95 \% \text { confidence } \\
\text { Interval of the } \\
\text { Differenses }\end{array}$} & & & \\
\hline & & & & Lower & upper & & & \\
\hline $\begin{array}{l}\text { Pretest } \\
\text { postest }\end{array}$ & -23.667 & 10.334 & 1.887 & -27.525 & -19.808 & -12.544 & 29 & .000 \\
\hline
\end{tabular}

Tabel uji t berpasangan terdiri dari atas 3 bagian penting pertama menunjukan bahwa nilai rata-rata peningkatan pestasi belajar mahasiswa sebelum dan sesudah menggunakan produk media aplikasi android adalah -23.667 dengan standar deviasi 10.334. Kedua pada tabel tersebut menujukan bahwa interval konvedensi $95 \%$ nilai rata-rata (sesudah dan sebelum menggunakan produk media aplikasi android) yaitu 
antara -27.525-19.808. Ketiga bagian yang menunjukan t hitung sebeaar -12.544 dengan 2-tailed 0.000

Pengambilan keputusan dalam uji Paired Sampele T-Test berdasarkan nilai signifikan dengan SPSS adalah:

a. Jika nilai Sig (2-tailed) $<0,05$, maka terdapat perbedaan yang signifikan antara hasil belajar pada data pretest dan postest yang artinya terdapat perbedaan hasil belajar penggunaan media apliasi android dalam pembelajaran bahas Arab nahwu mahasiswa Jurusan Bhasa dan Sastra Arab UIN Sunan Kalijaga Yogyakarta

b. Sebaiknya, jika nilai sig2 (2-tailed) $<0,05$, maka tidak terdaapat perbedaan yang signifikan antara hasil belajar pada pertest dan postest yang artinya tidak ada perbedaan haisl belajar penggunaan, media aplikasi android dalam pembeajaran bahasa Arab nahwu mahasiswa Jurusan Bahasa dan Sastra Arab UIN Sunan Kalijag Yogyakarta.

Berdasarkan output hasil tersebut maka dapat diketahui nilai sig (2-tailed) sebesar $0.000<0,05$, karena nilai sig (2-tailed) sebesar 0.000 lebih kecil dari 0,05 maka dapat disampaikan bahwa nahwu dapat meningkatkan hasil belajar mahasiswaa Jurusan Bahasa dan Sastrra Arab UIN Sunan Kalijaga Yogyakarta.

\section{Analisis data}

Setelah melakukan uji pra syarat dan uji hipotesa terhadap media aplikasi android untuk pembelajaran materi ilmu nahwu maka diperoleh data sebagai berikut:

a. Data nilai posttest berdistribusi normal dengan taraf signifikan 0.026 sedangkan nilai prtest berdistribusi normal dengan taraf signifikan 0.009

b. Data nilai pretest dan posttest bersifat homogeny dengan taraf signifikan, jadi keduanya mempunyai karakter yang sama 0.168

c. Terdaapat perbedaan prestasi belajar sebelum dan sesudah menggunakan media aplikasi android untuk pembelajaran materi ilmu nahwu sebelum menggunakan apliksi android untuk pembelajaran bahasa Arab ilmu nahwu rata-rata mahasiswa 60.33 dan sesudah menggunakan media aplikasi android untuk pembelajaran bahasa Arab ilmu Nhawu rata-rata prestasi belajar mahasiswa menjadi 84.00, jadi perbedaanya sangat signifikan dengan selisih 23.67

d. Hipotesa diterima dibuktikan dengan adanya nilai thitung lebih besar dari sig 2 tailed $<0,05$ yaitu $0,00<0,05$

e. Ada beberapa kelebihan medai aplikasi android untuk pembelajaran bahasa arab ilmu nahwu diantaranya adalah proses belajar dapat dilakukan dimana saja dan kapan saja, mengefisenkan waktu, mempermudah untuk mencari kata sulit yang dibantu mesin pencari aplikasi android tanpa menbongkar buku dan mebawa 
buku tebal kemana saja, serta dapat dibuka dengan mudah melalui handphone android mahasiswa dan lebih menyenagkan dalam belajar memahami kaidah nahwu.

f. Adapun kekurangan media aplikasi android untuk pembelajaran bahasa Arab ilmu nahwu diantaranya adalah mediahanya dapat diakses di smartphone android dan ios saja tidak dapat diakses melalui PC. Harus ada jaringan internet untuk mendownload aplikasi.

g. Adapun kendala dalam pemanfaatan media aplikasi andorid Arruz untuk pembelajaran bahasa Arab ilmu nahwu apabila smartphone mahsiswa berukuran mini akan merasa kesulitan untuk membaca penjelasan kaidah nahwu yang panjang.

h. Melalui pengamatan ketika diadakan pembelajaran menggunakan aplikasi android dilihat para mahasiswa tampak senang, semangat dan termotivasi untuk belajar kaidah nahwu lebih dalam. Dengan demikian dapat dikatakan bahwa media aplikasi android Arruz sangat efektif untuk digunakan dalam pembelajaran nahwu serta dapat meningkatkan penguasan dalam mengetahui kaidah nahwu dalam mebaca tulisan Arab gundul.

\section{E. Penutup}

Berdasarkan hasil penelitian yang telah dilakukan oleh penulis tentang media pembelajaran berbasis android dengan menggunakan aplikasi Arruz untuk penguasan nahwu maka dapat disimpulkan:

1. Penelitian pengembangan (research and devloment) model brog and gall yang media ini dilakukan dengan lima tahapan yaitu: 1) melihat potensi masalah 2). Melakukan analisis kebutuhan melalui observasi, studi literature, analisi karakteristik mahasiswa 3) menyusun produk awal, 4) mengevaluasi produk berdasarkan masukan ahli, 5) melakukan uji coba lapangan. Pengmbangan media pembelajaran nahwu menggunakan aplikasi Arruz merupakan aplikasi yang berupa kamus digital yang dapat memudahkan pengguna untuk mencari kata yang dicari dengan efisensi waktu yang hemat, tampilan awal dari aplikasi yang dibuat merupaka baiground serta logo Arruz dan papan ketik untuk mencari kata yang diinginkan, screen kedua berupa tampilan hasil dari mesin pencari kata, serta penjelasannya dan contoh yang lengkap dalam setiap penggunaan kata dalam kaidah bahasa Arab

2. Produk ini terbukti layak dengan dasar validasi oleh 2 ahli dibidangnya yaitu ahli deplover dan ahli materi serta 30 respon mahasiswa. Adapun responden 30 respon mahasiswa terhadap kualits media yang dikembangkan terdapat 2 aspek penilaian yaitu aspek desain dan aspek materi. Untuk aspek desain deketahui bahwa respon mahasiswa dengan total skor 4,3 atau dengan katagori baik. Sedangkan untuk aspek materi total rerata skor 4,2 dengan katagori baik. 
3. Penelitian nahwu dengan aplikasi android menunjukan data uji coba dengan pretest dan prosttes kepada 30 mahasiswa Jurusan Sastra Arab Fakultas Adab dan Ilmu Budaya UIN Sunan Kalijaga Yogyakarta. Dapat diketahui adanya peningkatan hasil belajar penggunaan media aplikasi Arruz dalam penerapan ilmu nahwu dengan hasil sig.(2-tailed) 0,000 yang lebih kecil dari 0,005, maka terdapat perbedaan yang signifikan hasil belajar dari sebelum penggunaan media apliksi dengan diketahui rata-rata sebelum penggunaan media aplikasi bahasa Arab berbasis android dengan menggunakan aplikasi Arruz sebesar 60,33 dan setelah penggunaan media aplikasi bahasa Arab berbasis android dengan aplikasi Arruz sebesar 84.00

Dengan demikian pembelajaran bahasa Arab ilmu nahwu yang berjudul Arruz direspon dengan positif oleh masiswa Jurusan Sastra Arab dan validator ahli serta dapat meningkatkan kemampuan penguasan kaidah ilmu nahwu mahasiswa sehingga media ini layak dan cocok untuk digunakan dalam proses pembelajaran bahasa Arab

\section{Daftar Pustaka}

Abdul Wahab Rosyid, Media Pembelajaran Bahasa Arab, UIN Malang press 2009, h (kata pengantar)

Purwo Wilayadi PLS UM, pemanfaatan perkembangan teknologi informasi dan Komunikasi untuk kemajuan pendidikan di Indonesia.jurnal ilmiah

Musyaroh, Mega. "pengembangan media pembelajaran berbasis android dengan menggunakan aplikasi android aplikasi adobe flash cs 6 pada mata pelajaran biologi”. Vol 6, Nomor 2 Desember 2017.

http:/ / lembing.com/ data-pengguna-smartphone-dan-social-media-2015/ diakses pada 1 Desember 2018

Direktorat Tenaga Kependidikan, Direktorat Jenderal Peningkatan Mutu Pendidik dan Tenaga Kependidikan, Pendekatan, Jenis, dan Metode Penelitian Pendidikan, (Departemen Pendidikan Nasional, 2008),

Sugiomo, Metode Penelitian Kuantitatif Kualitati Dan R\&D, (Bandung,:Alberta 2008

Sutrisno Hadi. Metode Penelitian Jilid I (yogyakarta: Andi Offset, 1993)

Sugiyono, metode penelitian pendidikan (pendekatan kunatitatif, kualitatif dan R\&D), (Bandung: Afabeta, 2012), cet. Ket-15

Anas Sudjono, Pengantar Statisitk Pendidikan, (Jakarta, Rajawali Pers, 2010)

Iqbal Hasaan, Analisi Data Penelitian dengan Statisitk, (Jakarta: PT Bani Aksara, 2004),

Anas Sudjono, Pengantar Statistic Pendidikan, (Jakarta: PT Raja Grafindo Persada, 2003), 